\title{
Gharib al-Hadits sebagai Embriologi Syarah Hadits dan Transformasinya
}

\author{
Nyayu Siti Zahrah \\ Universitas Islam Negeri Sunan Kalijaga Yogyakarta \\ e-mail: nszsarah95@gmail.com
}

\begin{abstract}
This paper aims to explain the meaning of the hadith, starting from its forerunner to its transformation at the present time. because it is often found a hadith text using language that is not easy to understand or has a vague meaning so that a precise and clear interpretation is needed so that the hadith is easily understood to be used as a guide and reference for the lives of Muslims in the world. The method used is a qualitative descriptive approach. The results of this paper indicate that the forerunner to the meaning of the hadith is based on the existence of the gharib hadith ie the hadith which is unclear or still vague, which is then interpreted and set forth in the book of Gharib al-Hadith with the method of tahlili, ijmali, and muqarrin and more tend to use the linguistic approach. But over time and the rapid development of science led to the emergence of a variety of new methods and approaches in interpreting a hadith, including hermeneutics and sociological approaches. So, the meaning that arises will be far more in accordance with the times, because the method and approach tries to interpret the hadith not only in terms of textual but also in terms of contextual.
\end{abstract}

Keywords: Gharib al-Hadits, Syarah Hadits

\begin{abstract}
Abstrak
Penelitian ini bertujuan untuk menjelaskan tentang pemaknaan terhadap hadits, mulai dari cikal bakal nya sampai pada transformasinya di zaman sekarang. karena sering ditemukan sebuah teks hadits menggunakan bahasa yang tidak mudah dipahami atau memiliki makna yang masih samar-samar sehingga diperlukan sebuah penafsiran yang tepat dan jelas agar hadits tersebut mudah dipahami untuk dijadikan sebagai pedoman dan acuan hiidup umat muslim di dunia. Adapun metode yang digunakan dalam penelitian ini yaitu dengan pendekatan deskriptif kualitatif. Hasil penelitian ini menunjukan bahwa Cikal bakal terjadinya pemaknaan terhadap hadits yaitu dilatar belakangi oleh adanya hadits gharib yakni hadits yang belum jelas atau masih samar-samar, yang kemudian ditafsirkan dan dituangkan dalam kitab Gharib al-Hadits dengan metode tahlili, ijmali, dan muqarrin dan lebih cenderung meggunakan pendekatan kebahasaan. Namun seiring berjalannya waktu dan pesatnya perkembangan ilmu pengetahuan menyebabkan munculnya berbagai metode dan pendekatan baru dalam menafsirkan sebuah hadits, di antaranya yaitu metode hermeneutika dan pendekatan sosiologis. Jadi, makna yang timbul akan jauh lebih sesuai dengan zaman, karena metode dan pendekatan tersebut mencoba menafsirkan hadits bukan hanya dari sisi tekstual namun juga dari segi kontekstualnya.
\end{abstract}

Kata Kunci: Gharib al-Hadits, Syarah Hadits 


\section{Pendahuluan}

Kurangnya pemahaman terhadap makna hadits merupakan problem yang di rasakan dari zaman dahulu sampai zaman sekarang. padahal hadits memiliki peran penting sebagai pedoman bagi umat Islam dalam menjalani kehidupan sehari hari, baik dalam ibadah, muamalah, adab maupun tuntunan yang lainnya. Selain itu, hadits juga berfungsi sebagai penjelas alQur'an yang masih bersifat global, agar menjadi terperinci dan mudah untuk dipahami. ${ }^{1}$ Hadits adalah perkataan, perbuatan dan ketetapan Nabi Muhammad Saw.2 Akan tetapi tidak semua hadits sudah mencantumkan secara jelas antara teks yang ada dengan makna teks yang sesungguhnya, dengan kata lain ada hadits yang masih perlu pemaknaan dalam memahaminya. Pemaknaan ini perlu dilakukan karena semua umat Islam memang memerlukan penjelasan dari sebuah hadits, mengingat kegunaan hadits juga masih eksis hingga masa sekarang,

\footnotetext{
${ }^{1}$ Ilham Firdaus Alviansyah, Abas Mansur Tamam, dan Nirwan Syafrin, "Konsep Pendidikan Perempuan Menurut Hadits-Hadits Dalam Kitab Riyadhus Shalihin Karya Imam AnNawawi," Tawazun: Jurnal Pendidikan Islam 10, no. 1 (19 Februari 2019): hlm. 72, https://doi.org/10.32832/tawazun.v10i1.1155.

2 Subhi as-Shalih, Membahas Ilmu-Ilmu Hadits (Jakarta: Pustaka Firdaus, 2009), hlm. 21.
}

karena memang hadits merupakan pedoman yang tak usang dimakan waktu dan tak usang dimakan zaman, walaupun terkadang penafsirannya berbeda karena disesuaikan dengan konteks nya.

Sebenarnya cikal bakal pemaknaan terhadap hadits sudah terjadi pada masa Rasulullah. Dimana hadits-hadits Rasulullah masih dipertanyakan maksudnya, hal ini dikarenakan hadits tersebut masih kurang jelas antara teks dan makna teks nya. Namun pada saat itu Rasulullah masih hidup dan pemaknaan hadits bisa langsung ditanyakan kepada Rasulullah untuk memperoleh penafsiran yang lebih jelas. Penafsiran atau pemaknaan dan penjelasan hadits ini dikenal dengan istilah syarah. Syarah adalah bentuk masdar, dalam bahasa Arab berasal dari lafadz dan mempunyai arti menjelaskan, menafsirkan, membeber-kan, jadi syarah mengandung arti suatu usaha menjelaskan atau mengungkap makna yang terdapat dibalik teks hadis. ${ }^{3}$ Pada masa sekarang ini pemaknaan terhadap teks hadits memang perlu dilakukan,

\footnotetext{
${ }^{3}$ Moh Muhtador, "Sejarah Perkembangan Metode dan Pendekatan Syarah Hadits," Jurnal Studi Hadits Vol. 2, no. 2 (2016): hlm. 261.
} 
karena teks adalah bahasa yang memiliki banyak aspek di dalamnya, yang berhadapan dengan konteks sosio budaya pada saat teks itu turun. Belum lagi, persoalan pelapor dan penulis yang memiliki latar belakang budaya yang beragama, dan juga masalah perjalanan waktu yang berabad-abad hingga sampai pada masa sekarang. ${ }^{4}$

Hadits yang belum jelas atau masih samar-samar maknanya disebut juga dengan istilah hadits gharib, sehingga menyebabkan terjadinya pensyarahan terhadap hadits. Syarah hadits pada masa Rasulallah yang berupa penjelasan lisan membuat ulama tergugah untuk membukukannya, mengingat perkataan lisan bukanlah hal yang bisa didokumentasikan pada saat itu. maka berawal dari hadits-hadits yang tidak jelas maknanya tersebut membuat terjadinya pensyarahan terhadap hadits yang awalnya dibukukan dalam kitab gharib al-hadits dan kemudian sekarang berkembang menjadi kitab-kitab syarah hadits.

Sebenarnya banyak penelitian yang pernah membahas gharib al-

\footnotetext{
${ }^{4}$ Muhammad Yusuf, Metode dan Aplikasi Pemaknaan Hadits (Yogyakarta: Bidang Akademik, 2008), hlm. 13.
}

Hadits maupun syarah hadits, antara lain yaitu dalam penelitian Muhammad Nabiel yang berjudul Metode Inerpretasi Gharib al-Hadits, penelitian ini menjelaskan tentang penafsiran gharib al-Hadits yang menggunakan beberapa pendekatan di antaranya yaitu melalui pendekatan ayat al-Qur'an, pendekatan riwayat yang semakna dan melalui pendekatan ahli bahasa. Pendekatan pertama adalah Penjelasan gharib al-hadits dengan pendekatan ayat al-Qur'an yaitu menjelaskan kata di dalam sebuah hadits yang masih ambigu dengan mengaitkannya pada ayat al-Qur'an yang memiliki relevansi dengan hadits tersebut. sehingga dapat menghasilkan sebuah makna. Dalam pendekatan kedua yakni penjelasan hadits dengan menggunakan pendekatan riwayat yaitu dengan melihat riwayat lain yang memiliki kesinambungan. Sedangkan pendekatan yang ketiga yaitu pendekatan melalui penjelasan ahli bahasa yakni menyingkap makna hadits dengan menggunakan syi'ir Arab sehingga segala hal yang masih bersifat ambigu dapat terungkap penjelasannya. Namun penelitian ini hanya terfokus 
menjelaskan hasil penafsiran dengan bebarapa pendekatan saja tanpa menjelaskan bahwa gharib al-Hadits itu merupakan awal dari cikal bakal munculnya syarah hadits. ${ }^{5}$

Penelitian lain yang membahas syarah hadits yaitu skripsi mahasiswa Universitas Islam Negeri Walisongo Semarang yang bernama Muhammad Nur Rokim, dengan judul Metode Syarah Hadits Salim Bin Id al-Hilali (Analisis Kitab al-Nadhirin Syarh Riyad al-Salihin). Skripsi ini membahas tentang metode pensyarahan dalam kitab al-Nadhirin Syarh Riyad al-Salihin adalah metode Ijmali yakni menjelaskan hadits secara global, kitab ini juga menggunakan metode maudhu'I yakni menjelaskan hadits berdasarkan tema yang pembahasannya dikumpulkan berdasarkan tema yang sama. Adapun pendekatan yang dipakai yaitu pendekatan linguistic dan pendekatan teologi normatif. 6

Penelitian lainnya yaitu tesis Hani Hilyati Ubaidah yang berjudul Kajian Syarah Hadits (Studi Teks Kitab Hadits," t.t.

${ }^{5}$ Muhammad Nabiel, “Metode Interpretasi Gharib al-

${ }^{6}$ Muhammad Nur Rokim, “Metode Syarah Hadis Salim Bin ‘Id Al-Hilali (Analisis Kitab Bahjah Al-Nadhirin Syarh Riyad Al-Salihin,” UIN Walisongo Semarang, 2017.
Misbah al-Zalam Syarh Bulugh alMaram min Adillati al-Ahkam). Penelitian ini membahas tentang metode yang digunakan dalam melakukan pensyarahan yaitu metode muqarrin yaitu membandingkan, sedangkan corak yang digunakan yaitu corak linguistic dan fiqh-ushul fiqh. ${ }^{7}$ Namun beberapa penelitian di atas hanya menjabarkan berbagai macam metode-metode yang digunakan dalam menafsirkan sebuah hadits tanpa mencari cikal bakal munculnya syarah hadits bahkan transformasi metode syarah hadits di zaman sekarang. Sehingga perlu dikaji lebih lanjut Bagaimana penjelasan syarah hadits di awal kemunculannya melalui gharib al-hadits dan Apa saja faktor-faktor yang melahirkan embrio gharib al-hadits serta bagaimana transformasi syarah hadits di zaman sekaarang?.

\section{Pembahasan}

\section{Kriteria Gharib al-hadits}

Hadits merupakan berbagai hal yang ditinggalkan oleh Rasulullah Saw yang berfungsi

\footnotetext{
7 Hani Hilyati Ubaidah, “Kajian Syarah Hadits (Studi Teks Kitab Misbah al-Zalam Syarh Bulugh al-Maram Min Adillati al-Hikam" (UIN Syarif Hidayatullah, 2019).
} 
sebagai petunjuk, baik berupa ucapan, perbuatan maupun ketetapan, serta sifat fisik dan psikis (akhlak), termasuk juga sejarah kehidupannya, baik sebelum beliau diutus sebagai Rasul maupun pasca pengutusannya tersebut. ${ }^{8}$ namun tidak semua hadits mencantumkan teks yang jelas atau mudah dipahami maksudnya, maka dari itu muncul istilah yang namanya gharib hadits. Gharib Hadits merupakan ungkapan dari lafadz-lafadz yang sulit dan rumit untuk dipahami yang terdapat dalam matan hadits karena lafadz tersebut jarang digunakan. ${ }^{9}$ Hal ini dikarenakan bahasa yang digunakan masyarakat telah berbaur dengan bahasa lisan atau bahasa arab pasar, sehingga terkadang tidak mengerti lafadz yang gharib. ${ }^{10}$ Bisa juga dikarenakan lafadz pada hadits tersebut jarang digunakan oleh Nabi Muhammad Saw, biasanya lafadz nya mengandung ungkapan

8 Rahendra Maya, "Konstruk Syarah Hadits Ahkam (Syarh Ahâdits Al-Ahkâm) dan Format Pembelajarannya di Perguruan Tinggi: Sebuah Tawaran Metodologis," Al-Mashlahah: Jurnal Hukum Islam dan Pranata Sosial Islam 6, no. 01 (2018): hlm. 25.

${ }^{9}$ Munzier Suprata, Ilmu Hadits, 2008 ed. (Jakarta: Raja Grafindo Persada, 2008), hlm. 40.

10 as-Shalih, Membahas Ilmu-Ilmu Hadits, hlm. 105. perumpamaan, sindiran dan lain sebagainya. ${ }^{11}$ Contoh hadits yang termasuk kategori gharib yaitu hadits tentang suara wanita adalah aurat. 12

Lalu gharib hadits ini bertujuan untuk menjelaskan hadits yang matannya terdapat lafadz yang pelik dan susah dipahami, sehingga gharib al-hadits inilah yang membantu memahami dan menjelaskan hadits tersebut. sebenarnya para ulama sudah menyusun tentang gharib al-hadits sejak abad kedua dan awal abad ketiga hijriyah bertepatan pada awal mula pembukuan hadits. Orang yang pertama menyusun dalam gharib al-hadits ialah Abu Ubaidah Mu'ammar bin al-Mutsanna atTaimi. ${ }^{13}$ Setelah munculnya gharib al-hadits, maka pada perkembangan selanjutnya para ulama mulai tergugah untuk menjelaskan katakata gharib dalam hadits tersebut dengan cara mensyarahkannya. Bahkan ada ulama yang sengaja

11 Tarmizi M. Jakfar, “'Ulum Al-Hadits Dan Korelasinya Dengan Ushul Al-Figh" 10 No. 1 (2013): hlm. 101. 12 Nixson Husin, "Suara Wanita (Tinjauan Mukhtalif al-Hadits)," Jurnal Ushuluddin 21, no. 1 (2015): hlm. 48.

${ }^{13}$ Syaikh Manna Al-Qaththan, Pengantar Studi Ilmu Hadits (Pustaka Al Kautsar, 2012), hlm. 95. 
mensyarahkan secara khusus tentang hadits yang terdapat katakata gharib. ${ }^{14}$ Jadi, gharib hadits yang memiliki kata yang kabur dan rumit untuk dipahami inilah yang menyebabkan para ulama untuk melakukan penjelasan terhadap hadits atau melakukan syarah hadits, dengan kata lain sebenarnya cikal bakal syarah hadits ini sebelumnya di dahului dengan adanya gharib al-hadits.

Adapun ragam kitab yang termasuk gharib hadits yaitu Kitab "Gharib A1-Hadits", karya Abul Hasan An-Nadhr bin Syumail alMazini (wafat $203 \mathrm{H}$ ), salah satu guru Ishaq bin Rahawaih, guru Imam Bukhari, lalu Kitab "Gharib Al-Atsar", karya Muhammad bin AlMustanir (wafat $206 \mathrm{H}$ ), selain itu Kitab "Gharib Al-Hadits" karya Abu Ubaid Al-Qasim bin Salam (wafat $224 \mathrm{H})$, lalu karya Abu Muhammad Abdullah bin Muslim bin Qutaibah Ad-Dainuri (watat $276 \mathrm{H}$ ) juga termasuk kitab gharib al hadits yang diberi nama kitab "Al-Musytabah min Al-Hadits wa Al-Qur'an".

14 Suprata, Ilmu Hadits, hlm. 41.
Selanjutnya yaitu Kitab "Gharib AHadits" karya Qasim bin Tsabit Tsabit bin Hazm Sirqisthi (wafat 302 H) dan Kitab "Gharib AL-Hadits", karya Abu Bakar Muhammad bin Al-Qasim al-Anbari (wafat $328 \mathrm{H}$ ) serta Kitab "Gharib al-Qur'an wa a;Hadits", karya Abu Ubaid AIHarawi Ahmad bin Muhammad (wafat $401 \mathrm{H}$ ), selain itu Abul Qasim Ismail bin al-Hasan bin at-Tazi alBaihaqi (wafat $402 \mathrm{H}$ ) juga menulis kitab gharib al-hadits yang diberi nama Kitab "Samthu Ats-Tsurayya fi Ma'ani Gharib Al-Hadits" , lalu Kitab "Majma' Ghara'ib fi Gharib AlHadits", Abul Hasan Abdul Ghafir bin Ismail bin Abdul Ghafir al-Farisi (wafat $529 \mathrm{H}$ ) dan Kitab "Al-Fa'iq fi Gharib Al-Hadits", karya Abul Qasim Jarullah Mahmud bin Umar bin Muhamad Az-Zamakhsyari (wafat $538 \mathrm{H}$ ), serta Kitab "AlMughits fi Gharib Al-Qur'an wa AlHadits", karya Abu Musa Muhammad bin Abu Bakar AlMadini Al-Ashfahani (wafat $581 \mathrm{H}$ ) dan Kitab "An-Nihayah fi Gharib AlHadits wa A-Atsar", karya Imam Majduddin Abu As-Sa'adat Al- 
Mubarak bin Muhammad Al-Jazari

Ibnu Al-Atsir (wafat $606 \mathrm{H}$ ). ${ }^{15}$

Sebenarnya ulama yang terakhir melakukan pembukuan dan penjelasan gharib al-hadits adalah Ibnu Atsir dan belum diketahui lagi siapa lagi yang menyusun gharib alhadits setelahnya kecuali Ibnu Hajib. Namun pada saat itu ulama-ulama lain hanya sebatas memberi lampiran dan ikhtisar atau meringkas terhadap kitab $A n-$ Nihayah. Ulama yang memberi lampiran pada kitab tersebut adalah Shafiyuddin Mahmud bin Abu Bakar al-Armawi (wafat $723 \mathrm{H}$ ) dan yang melakukan ikhtisar adalah Syaikh Ali bin Husamuddin alHindi, yang dikenal dengan alMuttaqi (wafat $975 \mathrm{H}$ ), Isa bin Muhammad as-Shafawi (wafat 953 H) kira-kira mendekati setengah ukuran kitab, dan Jalaluddin asSuyuthi (wafat $911 \mathrm{H}$ ), mukhtasharnya dinamakan "AdDurru an-Natsir Talkhis Nihayah Ibnu al-Atsir". Kitab Nihayah juga disusun dalam bentuk syair oleh Imaduddin Abu al-Fida Ismail bin Muhammad 95-96.
al-Ba'labaki al-Hanbali (wafat $785 \mathrm{H}$ ) dengan nama "Al-Kifayah fi Nudzum An-Nihayah"16

Banyak pendapat yang menjelaskan tentang cara pemaknaan hadits. Setiap zaman, setiap waktu dan setiap tempat memiliki perbedaan dalam menjelaskan gharib hadits maupun hadits-hadits lain yang perlu di syarah. Pada masa awal munculnya cikal bakal syarah hadits yaitu dari hadits gharib yang kemudian dibukukan dalam kitab gharib alhadits yang memiliki metode tersendiri dalam menafsirkan sebuah hadits. Untuk mensyarah sebuah hadits maka diperlukan penjelasan kata dan bagian-bagian hadits yang masih kabur. Kemudian dikaitkan dengan dalil lain yang ada persamaannya, lalu mengemukakan pengertiannya secara menyeluruh. ${ }^{17}$ Sebenarnya ada beberapa cara yang digunakan ulama terdahulu untuk menjelaskan atau mensyarah hadits khususnya gharib al-Hadits, caranya yaitu Pertama, dengan hadits yang

16 Al-Qaththan, hlm. 96-97.

17 Ahmad Husnan, Kajian Hadits Metode Takhrij, 1993 ed. (Jakarta: Pustaka Al Kautsar, t.t.), hlm. 94. 
sanadnya berlainan dengan matan yang mengandung lafadz gharib tersebut. kedua, dengan penjelasan akan makna gharib dari para sahabat yang meriwayatkan hadits dan paham makna gharib al-Hadits ataupun sahabat lain yang tidak meriwayatkan hadits namun paham dengan makna gharib al-hadits. Ketiga, penjelasan dari rawi selain sahabat.18 Awalnya penjelasan syarah hadits disampaikan secara lisan

\section{Faktor yang Melahirkan}

\section{Embriologi Syarah Hadits}

Salah satu faktor yang mmpengaruhi embriologi syarah hadits yaitu setting historis ulama syarah hadits abad ke 7. Dimana pada abad ke 7 merupakan masa gencarnya syarah hadits. Hal ini dilatarbelakangi oleh ulama pada masa itu sudah tidak sibuk lagi dengan urusan hadits, baik pengumpulan hadits meupun pembukuan hadits. Faktor lainnya yang menyebabkan fakta ini terjadi yaitu Kaum muslimin pada saat itu mulai terjadi kemunduran dan

18 Suprata, Ilmu Hadits, hlm. 41. mereka mulai mengkerdil dan hanya disibukan dengan tradisi melebarkan sayap keilmuan atau memberikan penjelasan terhadap temuan yang sudah ada dan tidak menemukan susuatu yang baru. Sehingga yang terjadi pada saat itu hanyalah memperlebar kajian yang sudah ada tanpa melahirkan karyakarya yang baru. Jadi, kondisi ulama pada saat itu memang hanya terfokus pada pemaknaan sebuah hadits sehingga hadits-hadits dapat dipahami dan diamalkan. ${ }^{19}$

$$
\text { Faktor lain yang }
$$
menyebabkan munculnya embriologi syarah hadits yaitu dari kecendrungan keilmuan pada abad ke 7 tersebut. dimana telah diketahui bahwa cikal bakal pensyarahan hadits yaitu dari adanya gharib alhadits, dan pemaknaan terhadap gharib hadits juga sudah diketahui berbagai metode yang digunakan pada saat itu yang dilatarbelakangi oleh kondisi ulama yang memang sudah tidak disibukan lagi dengan pengumpulan hadits-hadits maupun

${ }^{19}$ Muhammad Alfatih Suryadilaga, Metodelogi Syarah Hadits, 2012 ed. (Yogyakarta: Suka Press, t.t.), hlm. 910. 
pembukuan hadits, maka ulama pada saat itu memang terfokus pada pemaknaan hadits. Maka muncul banyak metode pensyarahanpensyarahan hadits, jadi seluruh hadits-hadits yang masih belum jelas akan di jelaskan lagi dengan berbagai metode pensyarahan hadits.

Kecenderungan keilmuan yang terjadi pada masa itu masih menggunakan corak kebahasaan, hukum tasawuf dan lain sebagainya. Sedangkan metode yang digunakan meliputi metode tahlili, ijmali dan muqarin. Pada metode tahlili, pensyarahan hadits lebih terperinci, sedangkan pada metode ijmali penjelasan hadits lebih bersifat global, namun pada metode muqarin biasanya lebih berupaya membandingkan hadits yang memiliki redaksi yang sama atau hadits yang redaksi berbeda namun memiliki kasus yang sama, terkadang metode muqarin ini hanya membandingkan pendapat ulama sebelumnya yang telah mensyarah sebuah hadits. ${ }^{20}$
Adapun salah satu contoh pengaplikasian syarah hadits pada abad ke 7 yaitu dengan menggunakan pendekatan kebahasaan. Contohnya yaitu dari sebuah hadits yang artinya:

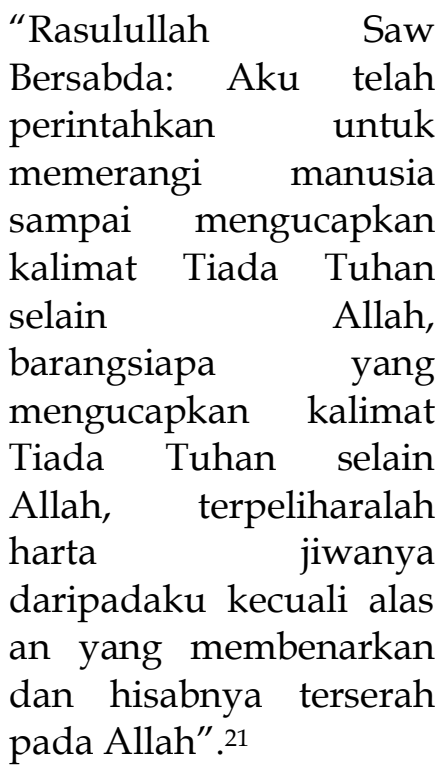

Terdapat dua kata untuk memahami hadits diatas yaitu kata amiru dan Uqatila. Kata amiru merupakan fi'il madhi yang berbentuk majhuk yang artinya diperintahkan atau tuntutan untuk melakukan sesuatu. Sedangkan kata Uqatila merupakan bentuk fi'il mudhari yang artinya memerangi. Jadi dapat dipahami bahwa perintah memerangi manusia pada hadits di atas adalah setelah adanya aksi dari

${ }^{21}$ Suryadilaga, hlm. 128. 
orang-orang musyrik. Secara bahasa makna perintah adalah wajib sehingga hal itu merupakan kewajiban. Sedangkan kata an-nass pada hadits tersebut memiliki arti bahwa yang diperangi bukanlah semua orang, namun hanya untuk orang yang dikhususkan yaitu orang-orang yang tidak mengucapkan syahadat yang memerangi orang Islam. ${ }^{22}$

\section{Transformasi Atas Pemahaman}

\section{Hadits Kekinian}

$$
\text { Terjadinya trasnformasi }
$$

pensyarahan hadits salah satunya disebabkan oleh kondisi keilmuan masa kini. Dimana tradisi memberikan syarah dalam dunia Islam sudah mengakar kuat, sehingga melahirkan para intelektual muslim. ${ }^{23}$ Bahkan seiring berkembangnya zaman dan ilmu pengetahuan, maka semakin banyak ide-ide baru yang muncul dalam melakukan pensyarahan terhadap hadits. Pada zaman modern ini sudah banyak berkembang ilmu

22 Suryadilaga, 128-29.

${ }^{23}$ Fatkhul Mukhlies, "Peranan Syaikh Mahfuzh AlTarmasi Dalam Perkembangan Ulum Al-Hadits: Studi Kitab Manhaj Dzawi Al-Nazhar" (PhD Thesis, UIN Sunan Ampel Surabaya, 2010), hlm. 70. pengetahuan yang baru yang merupakan buah hasil dari pemikiran manusia yang kritis, termasuk dalam uapaya pemaknaan terhadap hadits. Pemaknaan hadits yang dilakukan oleh ulama pada era modern ini yaitu dengan menggunakan pendekatan hermeneutika dan kebanyakan juga dengan menggunakan metode tematik dan kontekstual yakni disesuaikan dengan konteks zaman sekarang. Menurut Zygmunt Beuman, hermeneutika yaitu upaya dalam menjelaskan pengertian dasar dari suatu ucapan maupun suatu tulisan yang masih kabur atau belum jelas sehingga menimbulkan kebingungan bagi pendengar atau pembacanya. ${ }^{24}$ Jadi, jika hermeneutika di aplikasikan dalam upaya memahami hadits maka dapat diartikan bahwa hermeneutika hadits sebagai cara yang digunakan ulama untuk menjelaskan pengertian yang masih kurang jelas dari sebuah hadits. Contoh tokoh-tokoh yang berperan dalam memaknai hadits dengan

\footnotetext{
${ }^{24}$ Muhammad Yusuf, Metode dan Aplikasi Pemaknaan Hadits, (Yogyakarta: Teras, 2009), hlm. 14.
} 
pendekatan hermaneutika yaitu

Yusuf al-Qardawi, Syuhudi Ismail, Muhammad Iqbal dan Fazlur Rahman. ${ }^{25}$ Selain itu, perkembangan ilmu pada saat ini juga sudah bisa melahirkan pemaknaan hadits dengan menggunakan corak pendekatan yang diinterkoneksikan dengan ilmu lain misalnya ilmu sosial, humaniora, sains dan lain sebagainya. ${ }^{26}$

Ilmu yang berkembang kemudian yaitu hermeneutika dengan berbagai macam metode dan pendekatan baru. Salah satu pendekatan yang dipakai yaitu pendekatan sosiologis yang menyesuaikan hadits tersebut dengan konteks di zaman sekarang, karena perkembangan waktu dan perbedaan tempat disetiap negara melahirkan konteks yang berbedabeda sehingga diperlukan pemahaman yang bersifat kontekstualitas. ${ }^{27}$ ada juga dengan pendekatan fiqh, karena pada

25 Yusuf, hlm. 19.

26 Benny Afwadzi, "Hadis 'Man Baddala Dînahû Faqtulûhu': Telaah Semiotika Komunikasi Hadis," ESENSIA: Jurnal Ilmu-Ilmu Ushuluddin 16, no. 2 (1 Oktober 2015): hlm. 135, https://doi.org/10.14421/esensia.v16i2.992.

${ }^{27}$ Muhammad Alfatih Suryadilaga,

"Kontekstualisasi Hadits Dalam Kehidupan Berbangsa dan

Berbudaya," KALAM 11, no. 1 (2017): hlm. 219. dasarnya ilmu memang saling berkaitan, karena sesungguhnya mengkaitkan ilmu yang satu dengan ilmu yang lain yang memiliki keterkaitan memang sangat penting sebagai alat analisia. ${ }^{28}$ sehingga apa yang menjadi hukum dalam Islam dapat diselaraskan dengan hadits yang memiliki kesinambungan, sehingga makna yang akan timbul dalam upaya mensyarah sebuah hadits akan sesuai dengan hukumhukum yang ditetapkan dalam agama Islam.

Salah satu tokoh yang melakukan pemaknaan hadits dengan pendekatan hermeneutika adalah Fazlur Rahman. Fazlur Rahman adalah seorang pemikir Islam dibidang hermeneutika baik hermeneutika al-Qur'an maupun hermeneutika Hadits. Fazlur Rahman dilahirkan pada tanggal 21 September 1919 di wilayah india. Fazlur Rahman Menyelesaikan MA nya di Universitas Punjab pada tahun 1942 dan menyelesaikan doctor filsafatnya di Universitas

${ }^{28}$ Jakfar, “'Ulum Al-Hadits Dan Korelasinya Dengan Ushul Al-Fiqh," hlm. 99. 
Oxford pada tahun 1949.29 Pendekatan hermeneutika yang digunakan Fazlur Rahman ini dinamakan dengan penafsiran situasional atau bisa juga dikenal dengan pendekaatan sosiologis. Adapun cara pengaplikasian dari keilmuan hermeneutika yang digunakan oleh fazlur Rahman dalam memaknai hadits yaitu: dengan cara memahami makna dari sebuah teks hadits, lalu mencoba memahami latar belakang situasi pada saat hadits itu muncul termasuk asbabul wurud hadits. Kemudian hal yang tak kalah penting dalam langkah ini yaitu memahami petunjuk-petunjuk alQur'an yang relevan. kemudian hasilnya dapat diaplikasikan dan diadaptasikan dengan latar sosiologis pada masa sekarang. ${ }^{30}$ Sehingga pemaknaan terhadap hadits tersebut akan menghasilkan pemaknaan yang memang relevan digunakan pada masa sekarang.

Pemaknaan hadits tentang larangan wanita bepergian sendiri

${ }^{29}$ Musnur Hery, Wacana Islam Barat, 2001 ed. (Yogyakarta: Titian Ilahi Press, t.t.), hlm. 52.

${ }^{30}$ Yusuf, Metode dan Aplikasi Pemaknaan Hadits, 2009, hlm. 23. merupakan salah satu contoh transformasi atas pemahaman hadits kekinian. Hadits tersebut diriwayatkan oleh Bukhari yang artinya:

Ishaq bin Ibrahim al Hambali telah menceritakan kepada kami (al-Bukhari). Dia berkata: saya berkata kepada Abu Usamah, telah menceritakan kepada kalian Ubaidillah dari Nafi' dari Ibnu Umar ra, bahwa Nabi Saw bersabda "janganlah perempuan bepergian sejauh perjalanan tiga hari kecuali ada mahram bersamanya". (HR. Bukhari). ${ }^{31}$

Hadits lain yang menjelaskan tentang hal terkait yaitu hadits yang diriwayatkan oleh Muslim yang artinya:

Zubair Ibn Harb dan Muhammad Ibn alMutsanna bercerita kepada kami (alBukhari). Keduanya berkata: Yahya yaitu al-Qaththan bercerita dari Ubaidillah, Nafi memberi kabar kepadaku dari Ibnu

\footnotetext{
${ }^{31}$ Abdul Mustaqim, Paradigma Integrasi Interkoneksi dalam Memahami Hadits, 2008 ed. (Yogyakarta, t.t.), hlm. 10.
} 


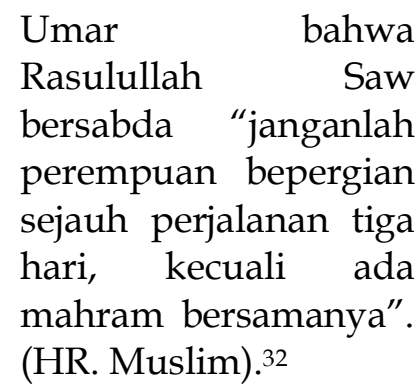

Jika ditafsirkan secara tekstual maka jelas hukumnya bahwa perempuan dilarang bepergian sendirian. Namun dengan pendekatan keilmuan masa kini yakni dengan hermeneutika dan pendekatan sosiologis, maka harus disesuaikan dengan kontekstualisasinya. Sehingga hadits tersebut dapat dimaknai dengan cara. Pertama, melihat setting historis dan keadaan sosiologis pada saat itu. Dimana keadaan sosiologis pada saat itu memang sangat cocok melarang wanita bepergian sendirian, hal ini dikarenakan pada saat itu memang wanita dianggap tidak etis jika bepergian sendirian. Selain itu, kekhawatiran Nabi juga menjadi pertimbangan pada keselamatan wanita saat bepergian jauh, hal ini dikarenakan kendaraan yang dipakai pada saat itu berupa unta atau keledai yang ditunggangi seraya melewati padang pasir yang sangat luas dan jauh dari manusia. Kedua. Melihat kondisi sosial pada masa sekarang. Dimana kondisi masyarakat pada masa sekarang sudah jauh berbeda, keselamatan sudah lebih terjamin, komunikasi dan transportasi sudah sangat canggih. Sehingga jarak tidak lagi menjadi masalah. sehingga dapat disimpulkan bahwa sah-sah saja jika perempuan hendak bepergian sendirian dengan jarak yang jauh, misalnya menuntut ilmu, bekerja, menunaikan ibadah haji atau umrah. $^{33}$ Jadi, dengan berkembangnya ilmu pengetahuan yang melahirkan ilmu pengtahuan baru yakni hermeneutika dengan berbagai macam pendekatan yang dapat mentransformasi syarah hadits, dapat menjadikan hadits lebih mudah dipahami dengan sifat kontekstual yang cocok di aplikasikan di zaman sekarang. 
Cikal bakal terjadinya pemaknaan terhadap hadits adalah dilatar belakangi oleh adanya hadits gharib yakni hadits yang belum jelas atau masih samar-samar. Sehingga pada saat itu ulama tergugah untuk menafsirkan sebuah hadits yang dituangkan dalam kitab gharib al-hadits agar menjadi jelas saat manusia mencoba mengaplikasikan hadits tersebut sebagai pedoman hidup. Lalu untuk meninterpretasikan hadits-hadits tersebut maka diperlukan sebuah metode dan pendekatan. Metodemetode yang digunakan dalam syarah hadits yaitu metode tahlili, ijlami, dan muqarrin. Adapun pendekatan yang dipakai yaitu pendekatan kebahasaan.

Namun seiring berjalannya
waktu, maka semakin pesat pula perkembangan ilmu pengetahuan yang menyebabkan munculnya berbagai metode dan pendekatan baru dalam menafsirkan sebuah hadits, sehingga pemaknaan terhadap hadits bisa dilakukan dengan ilmu hermeneutika dan menggunakan berbagai macam pendekatan seperti pendekatan sosiologis. Jadi, makna yang timbul akan jauh lebih sesuai dengan zaman karena pendekatan tersebut mencoba menafsirkan hadits bukan hanya dari sisi tekstual namun juga dengan melihat dari segi kontekstualnya.

\section{Referensi}

1. Afwadzi, Benny. "Hadis 'Man Baddala Dînahû Faqtulûhu' : Telaah Semiotika Komunikasi Hadis." ESENSIA: Jurnal Ilmu-Ilmu Ushuluddin 16, no. 2 (1 Oktober 2015): 135. https://doi.org/10.14421/esensia.v1 6i2.992.

2. Al-Qaththan, Syaikh Manna. Pengantar Studi Ilmu Hadits. Pustaka Al Kautsar, 2012.

3. Alviansyah, Ilham Firdaus, Abas Mansur Tamam, dan Nirwan Syafrin. "Konsep Pendidikan Perempuan Menurut Hadits-Hadits Dalam Kitab Riyadhus Shalihin Karya Imam An-Nawawi." Tawazun: Jurnal Pendidikan Islam 10, no. 1 (19 Februari 2019): 71-88. https://doi.org/10.32832/tawazun. v10i1.1155.

4. Hery, Musnur. Wacana Islam Barat. 2001 ed. Yogyakarta: Titian Ilahi Press, t.t.

5. Husin, Nixson. "Suara Wanita (Tinjauan Mukhtalif al-Hadits)." Jurnal Ushuluddin 21, no. 1 (2015): 48-61.

6. Husnan, Ahmad. Kajian Hadits Metode Takhrij. 1993 ed. Jakarta: Pustaka Al Kautsar, t.t.

7. Jakfar, Tarmizi M. "'Ulum Al-Hadits Dan Korelasinya Dengan Ushul AlFiqh" 10 No. 1 (2013).

8. Maya, Rahendra. "Konstruk Syarah Hadits Ahkam (Syarh Ahâdits Al- 
Ahkâm) dan Format

Pembelajarannya di Perguruan

Tinggi: Sebuah Tawaran

Metodologis." Al-Mashlahah: Jurnal

Hukum Islam dan Pranata Sosial Islam

6, no. 01 (2018): 23-48.

9. Muhtador, Moh. "Sejarah Perkembangan Metode dan Pendekatan Syarah Hadits." Jurnal Studi Hadits Vol. 2, no. 2 (2016).

10. Mukhlies, Fatkhul. "Peranan Syaikh Mahfuzh Al-Tarmasi Dalam Perkembangan Ulum Al-Hadits: Studi Kitab Manhaj Dzawi AlNazhar." PhD Thesis, UIN Sunan Ampel Surabaya, 2010.

11. Mustaqim, Abdul. Paradigma Integrasi Interkoneksi dalam Memahami Hadits. 2008 ed. Yogyakarta, t.t.

12. Nabiel, Muhammad. "Metode Interpretasi Gharib al-Hadits," t.t.

13. Rokim, Muhammad Nur. "Metode Syarah Hadis Salim Bin 'Id Al-Hilali (Analisis Kitab Bahjah Al-Nadhirin Syarh Riyad Al-Salihin." UIN Walisongo Semarang, 2017.
14. Shalih, Subhi as-. Membahas IlmuIlmu Hadits. Jakarta: Pustaka Firdaus, 2009.

15. Suprata, Munzier. Ilmu Hadits. 2008 ed. Jakarta: Raja Grafindo Persada, 2008.

16. Suryadilaga, Muhammad Alfatih. "Kontekstualisasi Hadits Dalam Kehidupan Berbangsa dan Berbudaya." KALAM 11, no. 1 (2017): 215-234.

17. - - - Metodelogi Syarah Hadits. 2012 ed. Yogyakarta: Suka Press, t.t.

18. Ubaidah, Hani Hilyati. "Kajian Syarah Hadits (Studi Teks Kitab Misbah al-Zalam Syarh Bulugh alMaram Min Adillati al-Hikam." UIN Syarif Hidayatullah, 2019.

19. Yusuf, Muhammad. Metode dan Aplikasi Pemaknaan Hadits. Yogyakarta: Bidang Akademik, 2008.

20. - - - Metode dan Aplikasi Pemaknaan Hadits. 2009 ed. Yogyakarta: Teras, 2009. 